\title{
Facilitating the Division of Matrimonial Property (Harta Sepencarian) through Hibah in Malaysian Shariah Court
}

Noorul Huda Sahari, Siti Khadijah Ab Manan, Rafeah Saidon, Amal Hayati Ishak Academy of Contemporary Islamic Studies, Universiti Teknologi MARA, 40450 Shah Alam, Malaysia

\begin{abstract}
Distribution of matrimonial assets or assets between spouses is often associated with unfairness to one of the parties, especially to the non-working wife. This is due to the fact that the current provision on the distribution of matrimonial assets emphasizes the contribution of the parties involved as the sole criteria in determining the proportion of their share. Though the law has not been amended to address this issue, it is observed that a transfer of ownership through hibah for the benefit of family members during marriage provides an alternative to the fairer distribution of matrimonial assets. Therefore, this study is undertaken to examine the applicability of hibah in dividing the assets through court practices. For that purpose, the study adopts a qualitative method which involves an analysis of unreported cases within the time frame of 2000-2012 collected from six zones representing Syariah Courts in Malaysia where analysis is made based on several variables such as types of matrimonial property, factors for consideration and proportion of distribution of the assets. Based on that sampling it has been discovered that the application of hibah in the division of matrimonial assets in the majority of cases is practically settled by way of sulh (amicable settlement). Ownership transfer of matrimonial assets especially through hibah could possibly serve in the best interest of the children and their needs as well as providing adequate security for the spouse. This has been successfully practiced in a polygamous marriage where a study shows that one party (husbands) are in fact more generous in dividing the assets, especially when dealing with the interests of their children. There were also cases where the husband was willing to transfer all assets to the existing wife which is rarely achieved in another litigation process. Thus, this study suggests that the hibah mechanism could be upgraded as law and to be widely practiced when dealing with the division of matrimonial assets.
\end{abstract}

\section{Key words: Division, Hibah, Harta sepencarian, Malaysia Shariah Court}

\section{INTRODUCTION}

Matrimonial assets or harta sepencarian generally refer to any property acquired during a marriage. Under Islamic Family Law Acts and Enactments, it is defined in the interpretation section. According to Section 2 of the Islamic Family Enactment (Selangor), 2003, (hereinafter referred to as the Islamic Family Law), harta sepencarian is interpreted as property jointly acquired by husband and wife during their subsistence of marriage according to Hukum Syarak. Section 122 of the same Act. It provides a specific provision on the division of matrimonial assets or harta sepencarian in Selangor. The provision requires the court to consider the contribution of all parties in acquiring the assets, interests of minor children, and debt of spouse in determining the share. The law and practice of division of matrimonial assets in the Shariah court emphasize the contribution of parties as to the sole criteria in determining the proportion of shares in the acquisition of assets. It is noted that the provision relating to the distribution of matrimonial assets in Malaysian Shariah Courts is considered unpractical and does not complement the actual mode of division of assets which is solely based on the contribution of said parties. The provision should focus on distributing the assets on a fair and equitable basis and should address the holistic needs of all parties involved. Though the law has not been amended to address the issue, it is observed that a transfer of ownership through hibah for the benefits of family members during marriage provides an alternative to a fairer distribution of matrimonial assets. In order to protect and safeguard the interest of the existing wife in regards to the matrimonial assets from dissipating to the other party, the newly embodied law empowers the court to divide the existing matrimonial assets upon the application for permission of polygamous marriage. The division is subjected to the principle of division embodied in section 122 of Islamic Family Law which requires the court to consider several factors including 
contribution, interests of minor children, and debt in determining the portion of the share. Thus, this paper is needed to identify the methods used in solving the dispute and hence, examine the effectiveness of the law through court practices. Hibah is one of the instruments in property division that is enforceable during the lifetime of the giver [1]. For the sake of this article, reference is made mainly to the relevant provision in the Islamic Family Law Enactment (Selangor), 2003.

\section{HIBAH ACCORDING TO ISLAMIC LAW AND ISLAMIC FAMILY LAW ENACTMENTS}

Hibah is a beneficiary contract which is defined as an agreement of property transfer completed during the lifetime of the donor which is voluntarily made without consideration (iwad) [2]. This contract is categorized as a contract of tabarru' with a similar effect as wasiat, gift, sadaqah, and wakaf where the principle is based on giving from one party to another without any consideration [3]. Though there is no specific enactment regulating the administration of hibah among Muslims, in practice the shariah courts do not prevent hibah to be carried out by Muslims. This has been highlighted in a number of research literature where there is a numerous cases involving hibah that had been litigated in the Shariah courts [4]. In the absence of a specific act relating to gifts, courts are at discretion in giving out judgment according to the stipulated law and follow the courts' view and consequently be fair to all parties involved [5]. The judicial decision in most cases is guided by the Islamic law of Imam Syafie. Hibah only applies after the fulfillment of the pillars of hibah that require the existence of offer and acceptance from the donor and receiver. Terms of sighah are the distinctive element differentiating between hibah and gifts even though both have similar implications with regards to the occurrence of property transfer from one party to another [6].

The law in Malaysia is silent with regards to the application of hibah in the division of matrimonial assets. However, Islamic Family Law Enactment highlights that the law protects the rights of the husband or wife to the matrimonial asset from being disposed to others without due knowledge. This has been provided in section 108 of the Islamic Family Law Enactments/Act that relates to the prohibition of the order of disposal of harta sepencarian.

Sec 108 (1) The Court may, on the application of any party to a marriage-

(a) where any matrimonial proceeding is pending in the Court; and

(b) in such proceeding, the Court may make an order under section 122, make an order prohibiting the wife or husband, as the case may be, from disposing of any property jointly acquired during the subsistence of their marriage if the Court is satisfied that it is necessary to do so. (2) Failure to comply with an order made under subsection (1) shall be punishable as contempt of Court.

\section{METHODOLOGY}

The case study was conducted on samples of unreported cases to examine the applicability of hibah in dividing the harta sepencarian or matrimonial assets based on the court practices in Malaysian Syariah Courts. Due to this, the study adopts a qualitative method which involves an analysis of unreported cases within the time frame of 2000-2012 collected from six zones representing Syariah Courts in Malaysia namely Selangor Shariah High Court, Penang Shariah High Court, Johor Bharu Shariah High Court, Kota Bharu Shariah High Court, and Kuching Shariah High Court. The content analysis was conducted on the 250 reported cases based on several variables such as types of matrimonial property, factors for consideration, and proportion of distribution of the assets.

\section{RESULT ANALYSES AND DISCUSSIONS}

\section{A. Sulh in the execution of Hibah involving Matrimonial Asset}

The law on the division of matrimonial assets emphasizes the fair distribution of the assets to the spouse by regulating the factors and considerations that the court has to take into account. This could be achieved by invoking sulh as an amicable settlement other than the normal litigation proceeding. Sulh is described as the result or finding from conciliation or mutual consent of disputed parties achieved through the mediation process [7]. Sulh is executed depending on the claim and application enunciated by the disputed parties. Observation on some cases signifies that sulh is a preferred method for settlement in the division of matrimonial property and it is also used in settlement of other matrimonial property disputes. Previous cases showed that the court was in favor to invoke sulh as an amicable settlement to guarantee fair division of harta sepencarian to both parties. Via sulh, the spousal agreement will be obtained on the essential elements and factors which are commonly disputed in normal proceedings for example the contribution of each spouse in acquiring the asset.

The study on 33 polygamy cases displays the practice of division of matrimonial property in the Syariah Courts in Malaysia like Selangor, Johor Bharu, Perak, Sarawak, and Penang except for the state of Kelantan due to the constraints in the jurisdiction of the court. Thus, this shows that 
division of assets during the marriage is practical and highly recommended to secure the existing assets from dissipating to other parties. The data displays the frequent and amicable settlement resulting by performing sulh. spouses were cooperative in agreeing on the important elements which can hardly be achieved during litigation processes. As an example, an agreement to declare an asset as matrimonial property and agreement to the portion of the share of matrimonial assets. This is illustrated in the case of Aminah Bt Berkatal v Mohd Shakdan B. Kamsah 10100-017-0120-2009 (Selangor) where the Shariah Court of Shah Alam ordered a matrimonial home be transferred to the plaintiff and the defendant agreed to forego his interest in the house. This case is a testimony that hibah on the matrimonial property occurred at the time of application for polygamous marriage is made or after divorce by mutual agreement. The transfer of matrimonial assets is taking into effect not only to a spouse but extended to their children of the marriage as well. Thus, the sulh mechanism in the division of matrimonial assets is deemed to be more practical. More consideration is given to the welfare of other family members especially so when the division involves a transfer of assets to the children and wife. The interests of a child are paramount and significant in the division to safeguard the child's interest after the husband or father commits polygamy although this is still not widely practiced. It can be concluded that sulh is an amicable settlement and its distribution is practical as parties' needs and children's interest become vital in ensuring fair and just division of assets.

Though the law emphasizes the power of the court to divide the property based on provided consideration, the party or parties are free to have the matrimonial property be transferred exclusively to any party or children as hibah. As far as the matrimonial asset is concerned, the practice of division through hibah also takes effect on the matrimonial property based on the practice in the Shariah Court.

\section{B. Hibah of Matrimonial Asset after Divorce}

It has been observed that the parties may agree to transfer a joint effort asset registered in joint names to one of the parties. It is depicted in the Selangor case of Norma Mokhtaram v. Kamaruddin B. Murat 12200-17-17-2000 (Selangor), where the court ordered that the defendant agreed to transfer his right to the plaintiff as the settlement of matrimonial property and agreed to cooperate in the transferring process. However, a house situated at Subang Jaya, Selangor registered under the defendant's sole name was ordered to be transferred to the plaintiff. The defendant agreed to pay the mortgage installments of the house until financing of the said property is concluded. This is illustrated in the cases of Nordalilati Hashim v. Erwan Zafry 10200-017-
0303-2009 (Selangor) and Khairul Hissam B. Portoo v. Noraini Othman; 10300-017-0054-2008 (Selangor) involving a house in a joint name each at $1 / 2$ part to the plaintiff and the remaining half to the defendant. Both agreed to transfer the house to the plaintiff and subsequently the plaintiff agreed to incur all liabilities related to the house. After the settlement, the plaintiff was required to pay RM10 000 to the defendant as reimbursement for the honesty of the defendant to transfer the house to the plaintiff. In the Selangor case of Alami Bt. A.Latif $v$ Mohd Yusof Bin Shamsuddin 10200-017-013-2001, the plaintiff, the former wife claimed her rights against a bungalow situated in Subang Jaya valued at RM1 million. The home was registered in the defendant's name and was purchased during the marriage. The plaintiff worked as a dentist and she also did household chores and took care of the family. The plaintiff claimed that during her studies in the UK, the defendant started his studies in law and she assisted the defendant to settle the education fees and bore some living costs and daily expenses from 1978 to 1983 . The court decided that on the agreement, the respondent agrees to the claim of the applicant against $70 \%$ of the net value of the matrimonial home. In the Penang case of Minah Binti Kassim v Anuar Bin Abu Bakar (07100-0170149-2003), it has been noted that the court ordered that RM20 000 be refunded to the plaintiff and in return, the plaintiff agreed to transfer a matrimonial home situated in Batu Feringghi to the defendant. The plaintiff contributed about RM17 000 for the construction and renovation of the house.

In a few cases, both parties agreed to waive their rights against the proportion of the matrimonial home and agreed to transfer their interests in the home to their children. In the Selangor case of Che Aminah Bt. Mohammed Saad v. Ibrahim B. Kassim 1220-17-17-2000 (Selangor) the court recorded a settlement of the matrimonial property where the defendant agreed to transfer a double-story terrace house situated in Subang Jaya, Selangor registered under the defendant's name to their four children. Hence, all expenses related to the renovation and maintenance of the house were to be borne by the defendant. Both parties also agreed to give the housing rent to the defendant. The defendant however, placed a condition pertaining to the house that no transaction was allowed without getting the defendant's approval. The court also ordered that the matrimonial house be transferred to the former wife and that she will be sharing the ownership of the matrimonial home with her children after the children attained the age of 18 (Rashid King @ Richard Alan King v. Syahriza Binti Jeli Bohari 13100-017-0298-2010 Sarawak).

In Sarawak, the transfer of matrimonial assets to children of the spouses was highlighted in several cases. For example, in the case of Sarinah Bt. Herry v. Khalid Bin Chek 13001-017- 0316-2010 
(Sarawak) the court ordered the defendant to transfer a house situated in Kuching, Sarawak to the children as soon as the mortgage payments of the house was completed. In the case of Suraiya Bt Mohd Latiff $v$. Hamizan Bin Bohan-13001-017- 0935-2004 (Sarawak) where the court ordered the transfer of the matrimonial home to two minor children to be effective after both children reach 18 years old. In the Sarawak case Hajakah @ Hajarah Binti Abdullah v. Mohd Hanif Bin Majimon (13100-0170255-2007) it was held that a house on customary land was granted to the defendant and seven children.

\section{Hibah of Matrimonial Asset upon polygamous Marriage}

Section 23(9) of the Islamic Family Law Enactment/Acts requires the husband to suggest a fair division of matrimonial assets acquired during the marriage of the existing wife before the husband can be allowed for polygamy [8]. This method is purposely to safeguard the interest of the existing wife and to protect the existing wife's interest from being dissipated by third parties after the practice of polygamy [9]. The cases showed that the court was in favor to invoke sulh as an amicable settlement to guarantee fair division of harta sepencarian to both parties. In sulh the meeting involved both parties and a sulh officer should be identified within 21 days after registration of the case. The agreement achieved will be endorsed and enforced by the court (MSS1/2002). Failure to reach for an agreement leads the case to be litigated in a normal proceeding [10].

The implication on the applicability of the law shows the division upon polygamy is well-practiced via sulh where the existing matrimonial asset is declared as a matrimonial asset and the parties will determine the appropriate proportion as their share in the existing matrimonial asset. Basically, contribution remains the main factor in determining the proportion of the share of the parties involved. However, when the division involved a spousal agreement, the court will no longer be subjected to the provided statutory law as the court is bound to order the division as specified in the agreement. Thus, in spousal agreement, other contributing factors are taken into consideration as well and the factors are the needs of both parties and children. This is an indication that the parties' desire is somewhat obsolete and the division is effective only after being endorsed by the court. For example- in the case of Zulkifli Bin Hj Saedun v. Zaimatun Bt. Hj Suradi 10100-011-0045-2008 (Selangor) the court ordered the house in dispute to be divided equally to the plaintiff and the defendant.

In the division of a matrimonial home, it was illustrated in some cases that the party agreed to transfer the whole ownership of the home to an existing wife. This highlights the extension to the original rule in practices of the division of matrimonial assets. In Aminah Bt. Berkatal v. Mohd Shakdan B. Kamsah (10100-017-0120-2009 (Selangor) the court held that based on the agreement of parties, the ownership of a terrace house situated in Shah Alam be transferred to the plaintiff and the defendant waived his right to claim the asset. Similarly, in the case of Mohd Isa B. Hashim v. Rusnah Ahmad (10300-011-0051-2006 Selangor), the court ordered the parties to adhere to the agreement endorsed regarding the division of harta sepencarian on an apartment situated in Puchong. In the Selangor case of Mohd Mohsi Bin Arsam v. Noraesah Bt Aman (10100-011-00092009) where the court held that the permission of polygamy has been allowed and the court ordered the division through sulh. The plaintiff has to surrender a terrace house situated in Johore Bharu and grant no. HSD 95452 also situated at in Johor Bahru, to the defendant. A Naza Ria car with registration number BJS 8983, is to be used as transportation by the defendant and their children. Another car, Wira TAD 983 was also ordered to be surrendered to the defendant.

Observation on several cases highlighted that when the matrimonial assets involved are multiples, the transfer of an asset to another party would depend on the type of agreement achieved. In other words, both parties get sole ownership of the asset by waiving each party's right towards another asset. In Akhbar Bin Ahmad v. Zaharah Bt Md Salleh (10300-011-0227-2007 (Selangor), after granting the permission to practice polygamy, the court ordered a house situated in Ampang, Selangor be transferred to the plaintiff. Another house situated in Bandar Ampang, Hulu Langat District under the ownership of the plaintiff was to be surrendered to the defendant. The division of the assets in some cases took into consideration the needs of the children of both parties where the children have been given a specific allocation as their share of hibah. In the Selangor case of Hj Sulaiman Abu Bakar v. Hjh Zainab Bt. Abd. Aziz (10300-011-0043-2007), the court ordered that a semidetached house situated in Negeri Sembilan and a terrace house in Johor Bahru be transferred to their children as hibah.

Exclusive transfer to the wife is another variation of the court order in the division of matrimonial home (Borhan Bin Ahmad v. Khadijah Binti Muslimin (07100-011-0280-2007 Penang); The exclusive transfer of ownership to the wife was also decided in the case of Yusni B. Mohd Yusof v. Narizan Bt Che Namat (08100-011-0007-2009 (Perak). The effective time of transfer takes place either at the time of granting the permission or after marriage to the subsequent wife. It happened in the Sarawak case of Rusli solihin v. Sabariyah Bt Udin (13100-011-0400-2012). This signifies that through sulh the need of an existing wife to the matrimonial home is prioritized for her survival in the future 
where the home is divided regardless of the number of the available matrimonial assets. This form of settlement should be seen as an appropriate division when involving cases of polygamy.

Based on the analysis, it can be concluded that the division of assets during the marriage is substantial and significant to ensure that polygamy does not affect the survival and security of the existing wife. One interesting aspect was that the division only involved the determination of shares of the asset which is not subjected to be sold. It has been observed that transfer of assets to the existing wife is common where this indirectly gives an advantage to the wife without the court emphasizing that contribution as sole criteria in dividing the share of assets. Thus, this shows that sulh is an amicable form of settlement for the division of matrimonial assets leading to a fair and just division of assets upon polygamy.

The data described that landed property, vehicles, shares, and business assets are part of the variation of assets involved in the division upon the husband getting permission to polygamy. It has been noted that overall there was no order given for these assets to be sold and the division be in a form of determining the portion of ownership on the assets. This highlights that the trend of the division during an existing marriage varies from other divisions where the determination of the proportion of the asset is made without any disposal of the asset. In a majority of cases, the court order the transfer of the entire interest in a vehicle to a wife. For example, in the case of Abdullah Bin Shikh Mohamed $v$. Ruhaidah Binti Ismail (01100-011-0040-2012 Johor), once the applicant agreed, the court ordered the transfer of the ownership of cars to the respondent and that the transfer be done ten days after the order of division issued by the court. In some cases, the vehicle was transferred to the wife and children (Wong SiewChoo@Badawi Abdullahv Jata (P) anak Unjah (13100-011-01092009(Sarawak) and when the available vehicles are multiple, the court ordered the vehicle to be exclusively transferred to the children (Hj Sulaiman Abu Bakar v. Hjh Zainab Bt. Abd. Aziz (10300-0110043-2007 (-Selangor).

The mutual agreement or sulh of parties promotes the need to take into account the interest and welfare of the children. It has been observed that mutual agreement to transfer the vehicle to the children is proved that the court is willing to expand the scope of division to children as hibah. This is illustrated in the case of Hj Sulaiman Abu Bakar v. Hjh Zainab Bt. Abd. Aziz (10300-011-0043-2007 (Selangor) where the court awarded their sons a car and two units of motorcycles whereas a Kelisa car was awarded to their daughter as a gift. This signifies that in the context of sulh during polygamy, besides considering the needs of both parties, the share for the children is also determined. It can be concluded that sulh of parties is an amicable settlement and its distribution is practical as the parties' needs and children's interests are the major considerations in ensuring a fair and just division upon polygamy.

The data indicates that out of the 13 studied cases, the division of properties also involved landed property (Abdul Aziz Bin Jelani v. Noriah Binti Norbi (07200-011-069-2007 (Penang), rental payments, business assets, savings and shares (Abdullah Bin Shikh Mohamed v. Ruhaidah Binti Ismail (01100-011-0040-2012-Johor) although there were rare. The division of these assets signifies the awareness of each party to divide any asset owned and the court has considerably expanded the scope of assets to be included in the division during marriage to tangible and intangible assets which are significant as they are high-value assets.

This was illustrated in the case of Abdullah Bin Shikh Mohamed v. Ruhaidah Binti Ismail (01100011-0040-2012-Johor) the existing marriage lasted about 20 years. The husband was a businessman who had accumulated several assets including shares and landed properties. The court, after endorsing the sulh of parties ordered out of the eight units of shophouses, four units to be surrendered and transferred to the respondent, the applicant's wife. The wife was also allowed to collect the rental payment of the shop. The court also ordered the business share owned by the applicant, LM Star Auto World Sdn. Bhd. to be divided at $15 \%$ to the respondent. The court ordered an ESSO petrol station under construction at the PLUS Highway to be surrendered to the wife and the wife to be given the rights to handle the business with the applicant bearing its capital finances. The court also ordered RM1million in saving monies to be deposited to the wife's Pilgrimage fund account within 60 days effective from the date of order. Besides, the court ordered cash monies amounting to RM 2 million to be deposited into the wife's RHB account from 20 until 28 February 2012

\section{Interests of Minor Children}

In cases where the division was made after divorce, the data describes that the needs of minor children are considered in sulh by allocating a portion of shares of the matrimonial assets to the children. This is common in Sarawak especially when the asset involved in the division is a matrimonial home. It has been observed that parties agreed to forgo their interests in the matrimonial assets and had also agreed to transfer their interest, in the assets to the parties' children. As regards the types of assets involved in the transfer these include land lots (Zarina Binti Yusoff v. Muhammad Bin Abdul Ghani 03100-01-0012-2003(Kelantan) and houses (Che Aminah Bt Mohammed Saad v. Ibrahim B.Kassim 1220-17-17-2000 (Johor). In Kelantan, the situation is the same. This was illustrated in the case 
of Zarina Binti Yusoff v. Muhammad Bin Abdul Ghani (03100-01-0012-2003(Kelantan). where the court ordered a transfer of an interest in two land lots and houses situated at Mukim Kenali, Kubang Kerian District, and Mukim Pasir Mas to all three children aged 11,16 , and 20 years in equal portions. The plaintiff and the defendant also agreed to be trustees for their minor children. It was noted that sole effort assets registered in the sole name of a party that was acquired during the marriage were also transferred to children. This is apparent in the case of Che Aminah Bt. Mohammed Saad v. Ibrahim B. Kassim (1220-17-17-2000 (Johor) where both parties agreed to transfer their interest in a doublestory terrace house situated at Subang Jaya, Selangor which was registered under the sole name of the defendant to four of the children. All expenses related to maintenance and renovation of the said house were to be incurred solely by the defendant.

The transfer of the interest of matrimonial home to children also takes effect when stipulated by the agreement of parties. In the case of Roslinah Che Wan v. Azlan B Sabtu (10200-017-0009-2008 (Selangor), the court ordered a double-story terrace house be considered as matrimonial property and the said house to be transferred wholly to the plaintiff with the mortgage installments of the house to be continued to be paid by the defendant until 2029. A condition is imposed that if the plaintiff then wants to get married to another man, the plaintiff has to transfer the assets to the children as hibah. However, in the case of Mohd Mujiar Kadisan v. Fatimah Binti Main (10100-017-05-2001(Selangor) the defendant, the former wife waived her right against the matrimonial property on a house situated at Bandar Baru Sg. Buloh, Selangor. In return, the house was to be sold at the original price of RM55 000 to their son soon after he obtains a permanent job. The plaintiff allowed the defendant to stay at the house with a rental of RM150 until the completion of the sale of the house.

The division upon polygamy, the data shows that six out of 14 cases attended to the welfare of children thus taking into account the division of the matrimonial asset through the spousal agreement. This is to protect the parties' welfare and well-being and also to ensure the children's security and stability. In the division of assets, it has been observed that the greater portion of share is granted to children of a spouse as hibah and the division involved a variation of assets such as share, matrimonial home (Wong Siew Choo@Badawi Abdullah v. Jata (P) anak Unjah 13100-011-01092009 (Sarawak), shop houses, vehicles (Hj. Sulaiman Bin Abu Bakar v. Hjh Zainab Bt. Abd. Aziz 10300-011-0043-2007(Selangor) and cash monies. However, the allocation of share to children does not prejudice the right of an existing wife to harta sepencarian and when the division to minor is only made available if multiple assets are involved. In
Johor Bharu, in the case of Abdullah Shik Mohammad v. Ruhaidah Binti Ismail (01100-0110040-2012 (Johor) wherein allowing the respondent husband's application for polygamy, despite the appropriate proportion allocated to the homemaker wife, the court ordered the plaintiff to transfer four units of houses to their two sons and two daughters including one minor daughter and to deposit in Tabung Haji account cash monies amounting to RM 1 million. The applicant also agreed to divide business shares owned by the applicant to the respondent that is $15 \%$ of the total share. However, the remaining $25 \%$ of shares were to be given to their two sons, and $10 \%$ share each to the other two daughters.

Adult Children are not excluded from receiving their proportion as a gift. This is illustrated in the case of Hj. Sulaiman Abu Bakar v. Hjh Zainab Bt. Abd. Aziz (10300-011-0043-2007 (Selangor) where the parties transferred whole interest in the asset to their son and daughter who were at the time of the division were at majority age. Here the courts ordered a car and two units of motorcycles to be transferred to their son, whereas the Kelisa car is to be given as hibah to their daughter. This shows that in the context of sulh during polygamy, besides considering the welfare of parties, the interest of children has also become pertinent in the division of assets.

\section{CONCLUSIONS}

The application of hibah in the division of matrimonial assets is practically settled by way of sulh (amicable settlement) of the parties. Ownership transfer of matrimonial assets especially through hibah could serve the best interest of children and their needs as well as provide adequate security for the spouse. in a polygamous marriage, hibah is practically applied in the division of matrimonial property where the parties (husbands) are in fact more generous in dividing the assets, especially when dealing with the interest of children to the level that the husband is willing to transfer the whole interest in the asset to the existing wife which is rarely achieved in another litigation process. Thus, this study suggests that hibah mechanism could be legislated and widely practiced in dividing the matrimonial property.

\section{ACKNOWLEDGEMENT}

This work was supported in part by Universiti Teknologi MARA (UiTM) under Grant No. 600-IRMI/Dana KCM 5/3/LESTARI (124/2017).

\section{REFERENCES}

[1] Badruddin Haji Ibrahim. (2009). Perkembangan dan Isu Undang-undang Hibah Orang Islam di 
Malaysia. In Pentadbiran Undang-undang Islam di Malaysia ed. Mahamad Ariffin, V.12, p. 140 .

[2] Mustafa al-Khin, Mustafa al-Bugha \& Ali alShirbaji. (1420/2000). Al-Fiqh al Manhaji. $4^{\text {th }}$ ed. Damascus: Dar al-Qalam, V. 3. pp. 101102

[3] Muhammad Mustafa Shalabi. (1421/2000). AlMadhkhal fi al-Ta'rif bi al Fiqh al-Islami wa Qawaid al-milkiyyah wa al-Uqud Fihi. Beirut:Dar al-Nahdah al-Arabiyyah, pp.567

[4] Badruddin Haji Ibrahim. (2009). Perkembangan dan Isu Undang-undang Hibah Orang Islam di Malaysia. In Pentadbiran Undang-undang Islam di Malaysia ed. Mahamad Ariffin , V.12, p. 140

[5] Badruddin Haji Ibrahim. (2009). Perkembangan dan Isu Undang-undang Hibah Orang Islam di Malaysia. In Pentadbiran Undang-undang Islam di Malaysia ed. Mahamad Ariffin , V.12, p. 140

[6] Badruddin Haji Ibrahim. (2009). Perkembangan dan Isu Undang-undang Hibah Orang Islam di Malaysia. In Pentadbiran Undang-undang Islam di Malaysia ed. Mahamad Ariffin, V.12, p. 140

[7] Siti Noraini $\mathrm{Bt} \mathrm{Hj}$ Mohd Ali. (2008). Perlaksanaan Sulh dan Aplikasinya di Jabatan Kehakiman Shariah Negeri Selangor. in Shariah Law Reports, vol 3, p.1.

[8] Norliah Ibrahim(2007). Harta sepencarian di Malaysia, in Undang-undang Keluarga Islam. Najibah Mohd Zain, Kuala Lumpur: Dewan Bahasa dan Pustaka.

[9] Roslina Che Soh@ Yusoff. (2007). Penyeragaman Undang-undang Poligami, in Undang-undang Keluarga Islam. Najibah Mohd Zain, Kuala Lumpur: Dewan Bahasa dan Pustaka, p.57.

[10] Nora Abdul Hak. (2007). Sulh dan Penyelesaian kes Keluarga, in Undang-undang Keluarga Islam. Najibah Mohd Zain et.al, Kuala Lumpur: Dewan Bahasa dan Pustaka, ,p.94.

Enactments

Islamic Family Law (State of Selangor) Enactment 2003

Circular of Chief Judge MSS 1/2002 (Code of Ethics of Sulh Officer and Sulh Work Manual)

Circular of Chief Judge MSS 9/2002 